\title{
Characterization of 14 Microsatellite Markers for Genetic Analysis and Cultivar Identification of Walnut
}

\author{
Gerald S. Dangl \\ Foundation Plant Services, University of California, One Shields Avenue, Davis, CA 95616
}

Keith Woeste

USDA Forest Service, Hardwood Tree Improvement and Regeneration Center, Department of Forestry and Natural Resources, Pfendler Hall, Purdue University, 715 West State Street, West Lafayette IN 47907-2061

\author{
Mallikarjuna K. Aradhya, Anne Koehmstedt, and Chuck Simon ${ }^{1}$ \\ National Clonal Germplasm Repository, U.S. Department of Agriculture, Davis, CA 95616 \\ Daniel Potter, Charles A. Leslie, and Gale McGranahan² \\ Department of Pomology, University of California, One Shields Avenue, Davis, CA 95616
}

AdDITIONAL INDEX wORDs. Juglans regia, SSR markers, DNA fingerprinting

\begin{abstract}
One hundred and forty-seven primer pairs originally designed to amplify microsatellites, also known as simple sequence repeats (SSR), in black walnut (Juglans nigra L.) were screened for utility in persian walnut (J. regia L.). Based on scorability and number of informative polymorphisms, the best $\mathbf{1 4}$ loci were selected to analyze a diverse group of 47 persian walnut accessions and one J. hindsii (Jepson) Jepson ex R.E. Sm x J. regia hybrid (Paradox) rootstock. Among the 48 accessions, there were 44 unique multi-locus profiles; the accessions with identical profiles appeared to be synonyms. The pairwise genetic distance based on proportion of shared alleles was calculated for all accessions and a UPGMA (unweighted pair group method with arithmetic mean) dendrogram constructed. The results agree well with what is known about the pedigree and/or origins of the genotypes. The SSR markers distinguished pairs of closely related cultivars and should be able to uniquely characterize all walnut cultivars with the exception of budsports. They provide a more powerful and reliable system for the molecular characterization of walnut germplasm than those previously tested. These markers have numerous applications for the walnut industry, including cultivar identification, verification of pedigrees for cultivar and rootstock breeding programs, paternity analysis, and understanding the genetic diversity of germplasm collections.
\end{abstract}

The persian walnut cultivars currently grown in California are the product of more than 200 years of cultivation in the state. The University of California (UC)-Davis Walnut Breeding Program, begun in 1948, produced many cultivars that contribute to the prominence of the California industry in the world market (Tulecke and McGranahan, 1994). The materials used to develop these cultivars originated in various parts of the world, including Europe, South America (where they were first brought from Europe by Spanish settlers), and Asia.

Several techniques have been used to examine genetic diversity and relationships among cultivars of persian walnut, including isozymes (Arulsekar et al., 1985; Solar et al., 1993, 1994), restriction fragment-length polymorphism (RFLP) (Fjellstrom et al., 1994), randomly amplified polymorphic DNA (RAPD) markers (Nicese et al., 1998), and, most recently, inter-simple sequence

Received for publication 8 July 2004. Accepted for publication 29 Aug. 2004. We gratefully acknowledge financial support from the Walnut Marketing Board, the California Dept. of Food and Agriculture, and the Genetic Resources Conservation Program at Univ. of California-Davis. Mention of a trademark, proprietary product, or vendor does not constitute a guarantee or warranty of the product by the U.S. Dept. of Agriculture and does not imply its approval to the exclusion of other products or vendors that also may be suitable.

${ }^{1}$ Current address: Chuck Simon, USDA, ARS PGRU, Cornell University, Collier Dr., Geneva, NY 14456-0462.

${ }^{2}$ To whom reprint requests should be addressed. E-mail address: ghmcgranahan @ ucdavis.edu; phone 530-752-0113; fax 530-752-8502. repeat (ISSR) markers (Potter et al., 2002a). These studies reflect the need for accurate cultivar identification (genetic fingerprints), and for verification of paternity and genealogy.

Microsatellite (SSR) markers are well suited to meet these needs. In addition, SSR markers informative in $J$. regia may also be polymorphic in other Juglans L. species (Aldrich et al., 2003) and have utility for breeding hybrid rootstocks. Paradox, an important rootstock in the California walnut industry, is generally produced by open-pollination of J. hindsii by J. regia. SSR markers will be useful for determining the specific J. regia cultivar or other species involved in the production of Paradox hybrids, a level of precision not heretofore possible (Potter et al., 2002b). SSR-based paternity analysis can also contribute to an understanding of pollen flow within and among walnut orchards: a critical issue as pollen is the vector for blackline disease (Mircetich et al., 1985) and because surplus pollen from pollinizers can result in yield loss from pistillate flower abscission (McGranahan et al., 1994).

Simple sequence repeat markers also have proven useful in the repository setting (Mitchell et al., 1997) to examine potential redundancies and propagation errors within collections (Dangl et al., 2001; Phippen et al., 1997). Thus, a short-term goal of this research was to identify SSRs for characterizing the UC-Davis and U.S. Dept. of Agriculture (USDA) walnut germplasm collections based on SSR loci identified in J. nigra (Woeste et al., 2002). 


\section{Materials and Methods}

Plant material and DNA extractions. Forty-seven accessions of $J$. regia, including many cultivars and selections from the UC-Davis Walnut Breeding Program, and one J. hindsii $\times$ J. regia hybrid rootstock, were selected for this study (Table 1). The accessions represent more than $90 \%$ of the currently cultivated cultivars. Two trees of each cultivar were tested (one tree from Wolfskill Experimental Orchard, Winters, Calif., and one from New Stuke Block on the UC-Davis campus). Only one tree of the plant introduction (PI) 159568, located at Wolfskill, was available. Young leaves were collected on two occasions from each tree. The first samples were ground in liquid nitrogen and DNA extracted using the method of Doyle and Doyle (1987) with an additional chloroform extraction step. A second set of samples was rapidly dried using Drierite (W.A. Hammond Drierite Co., Xenia, Ohio). Approximately $20 \mathrm{mg}$ of dried young leaf tissue were ground in liquid nitrogen and the DNA extracted using a DNeasy Plant Mini Kit(QIAGEN, Valencia, Calif.). DNAquality and quantity were determined using $2 \%$ agarose gels (SeaKem, Cambrex Bio Science, East Rutherford, N.J.) stained with ethidium bromide and visualized using ultraviolet (UV) light. As both DNA samples from both trees of a given cultivar generated an identical genotype based on SSR profiles, this genotype was treated as one result for further analysis.

PCR AMPLIFICATION. Genomic DNA was diluted to approximately $25 \mathrm{ng} \cdot \mu \mathrm{L}^{-1}$ in water. Polymerase chain reactions were conducted in a total volume of $15 \mu \mathrm{L}$ containing $5 \mathrm{ng} \cdot \mu \mathrm{L}^{-1}$ DNA, 1X Gold Buffer [Applied Biosystems Inc., Foster City, Calif. (ABI)], $2 \mathrm{~mm} \mathrm{MgCl} 2,0.2 \mathrm{~mm}$ each dNTP, $0.2 \mathrm{pmol} \cdot \mu \mathrm{L}^{-1}$ each primer and 0.024 units $/ \mu \mathrm{L}$ AmpliTaq Gold DNA polymerase (ABI). The thermal cycle profile for all primers was $5 \mathrm{~min}$ at 94 ${ }^{\circ} \mathrm{C}, 30$ cycles of $30 \mathrm{~s}$ at $94^{\circ} \mathrm{C}, 1 \mathrm{~min}$ at $58^{\circ} \mathrm{C}$, and $40 \mathrm{~s}$ at $72{ }^{\circ} \mathrm{C}$, concluding with 1 cycle of 2 min at $72^{\circ} \mathrm{C}$.

Fragment SEParation AND Sizing. Amplified fragments were separated by capillary electrophoresis on an ABI Prism 310 Genetic Analyzer using a $47 \mathrm{~cm} \times 5 \mu \mathrm{m}$ capillary with POP4 as the matrix (ABI). Run parameters were: travel length $30 \mathrm{~cm}$, run time $24 \mathrm{~min}$, electrophoresis power $15 \mathrm{kV}$, and temperature 60 ${ }^{\circ} \mathrm{C}$. Forward primers were labeled with one of the three dyes of Virtual dye Set $\mathrm{D}(\mathrm{ABI})$; the fourth dye was the tag for the internal size standard (400HD-ROX;ABI). During the initial screening of primer pairs, color multiplexing allowed analysis of three primer pairs per injection. In later phases of screening, size multiplexing (combining markers with non-overlapping fragment size ranges) was used in combination with color multiplexing. Depending on the concentration of amplified product, injection samples were prepared by mixing $0.6-0.8 \mu \mathrm{L}$ of amplified product from separate reactions with $0.74 \mu \mathrm{L}$ of size standard and $9.26 \mu \mathrm{L}$ of formamide. Fragment size in absolute base pairs was determined using GeneScan Analysis Software 3.1 (ABI) using local southern option as the size calling method. Peak binning and label editing were performed using GenoTyper version 2.5 (ABI).

SCREENING OF PRIMER PAIRS. Primer pairs designed to amplify SSRs in J. nigra (Woeste et al., 2002) were initially screened against $12 \mathrm{~J}$. regia accessions (Table 1). Priority was given to the most polymorphic markers with peaks that could be scored easily. The secondary primer screen consisted of the accessions in the primary screen as well as 12 other accessions (Table 1).

Data ANaLYsis. Observed heterozygosity $\left(\mathrm{H}_{\mathrm{O}}\right)$ and null allele frequency estimates were calculated for each locus using the
Table 1. Juglans regia cultivars, selections, and hybrid investigated in this study.

\begin{tabular}{|c|c|c|}
\hline Accession & $\mathrm{UCD}^{\mathrm{z}}$ accession no. & Nation of origin \\
\hline UC56-224y & UC56-224 & USA \\
\hline UC59-124 & UC59-124 & USA \\
\hline UC61-25 & UC61-25 & USA \\
\hline UC67-13x & UC67-13 & USA \\
\hline UC86-011 & UC86-011 & Germany \\
\hline Alsoszentivani-117x & UC85-042 & Hungary \\
\hline Amigo $^{y}$ & UC56-226 & USA \\
\hline Ashley & UC4 & USA \\
\hline Badajoz & UC87-002 & Spain \\
\hline Carmello & UC29 & USA \\
\hline Cascade & UC87-18 & USA \\
\hline Chandlery & UC64-172 & USA \\
\hline Chico $^{y}$ & UC56-206 & USA \\
\hline Cisco $^{y}$ & UC66-178 & USA \\
\hline Conway Mayettey & UC31 & USA \\
\hline Early Ehrhardt & UC6 & USA \\
\hline Eurekay & UC7 & USA \\
\hline Franquette $^{x}$ & UC96-002 & France \\
\hline Graves Franquette & UC32 & USA \\
\hline Gustine & UC52-061 & USA \\
\hline Hartley & $\mathrm{UC} 2$ & USA \\
\hline Howardy & UC64-182 & USA \\
\hline Lara & UC86-016 & France \\
\hline Lompoc $^{x}$ & UC52-046 & USA \\
\hline Lozeronne & UC92-002 & France \\
\hline Manregian (PI18256) & UC49 & China \\
\hline Marchettiy & UC41 & USA \\
\hline Meylany & UC42 & France \\
\hline Midland & UC49-047 & USA \\
\hline Paradox Burbankw & UC45 & USA \\
\hline Payne $^{x}$ & UC1 & USA \\
\hline Pedroy & UC53-113 & USA \\
\hline PI159568 & DJUG 99v & Afghanistan \\
\hline Pioneer & UC51-170 & USA \\
\hline Placentia & UC51 & UNK \\
\hline Poe & UC91-136 & USA \\
\hline Scharsch Franquette & UC3 & USA \\
\hline Serr ${ }^{x}$ & UC59-129 & USA \\
\hline Sharkeyy & UC53 & USA \\
\hline Sinensis- $5^{x}$ & UC54 & Japan \\
\hline Sunland ${ }^{\mathrm{x}}$ & UC66-004 & USA \\
\hline Tehamax $^{x}$ & UC58-011 & USA \\
\hline Tularex $^{x}$ & UC67-011 & USA \\
\hline Vina & UC49-049 & USA \\
\hline Waterloo $^{x}$ & UC56 & USA \\
\hline Weeper & UC84-006 & USA \\
\hline Xinjiang-6 & UC85-008 & China \\
\hline xxxMayette & UC58 & USA \\
\hline
\end{tabular}

$\overline{ } \overline{ }$ Univ. of California at Davis.

yTwelve additional accessions used in the secondary screen.

${ }^{x}$ Twelve accessions used as the primary screen.

${ }^{\mathrm{w} J}$. hindsii $\mathrm{x} J$. regia hybrid.

vAccession number from National Clonal Germplasm Repository, Davis, Calif. 
CERVUS 2.0 software package (Marshall et al., 1998). Negative values for null allele frequency estimate imply observed heterozygote genotypes in excess of statistical expectations (Marshall et al., 1998). The unbiased total probability of identity given two randomly selected, unrelated individuals from a randomly mating population with the observed allele frequencies [P(ID)] was calculated for the entire data set and on a per locus basis as described in Paetkau et al. (1995, 1998), as a means of assessing the power of each microsatellite to contribute to a unique genotype for each accession (Table 2). Allele frequencies were calculated based on observed values. The pairwise genetic distance [1 - (proportion of shared alleles)] (Bowcock et al., 1994) was calculated with Microsat 1.5 (Minch et al., 1997). A dendrogram based on the genetic distance values was constructed using UPGMA (Sneath and Sokal, 1973).

\section{Results and Discussion}

A total of 147 primer pairs was tested for their ability to amplify fragments in 12 accessions of J. regia (Table 1). Products from 66 primer pairs were analyzed by capillary electrophoresis. The loci were ranked based on the amount of polymorphism, particularly in regard to their ability to distinguish closely related cultivars in the primary screen (Fig. 1). High priority was also given to loci with alleles that could be scored accurately and precisely.

Fourteen loci (Table 2) were selected to analyze the full set of 48 accessions producing 44 unique multi-locus profiles. The accessions that had identical profiles will be discussed later. Comparison of the published pedigrees showed that, with few exceptions, the fragments behaved as alleles of segregating loci and from here forward will be referred to as alleles. Allelic data for 12 diverse and economically important accessions of J. regia are presented (Table 3 ) for use as size standards to assist in correcting lab-to-lab variation of allele size calling that may result from differences in methodologies (This et al., 2004).

Despite multiple attempts, 'Meylan' could not be amplified at WGA349, and Paradox 'Burbank' could not be amplified at WGA331. Overall, however, we observed a low frequency of null alleles. The failures of WGA349 to amplify any of the four DNAs of 'Meylan' and WGA331 to amplify any of the four DNAs of Paradox 'Burbank' appear to represent genuine double nulls. 'Meylan', a parent of 'Cisco' (Fig. 1), may not have been the only source of the null at WGA349 since this locus had the highest estimated frequency of null alleles (Table 2). Some of the allelic data at WGA349, and only WGA349, are inconsistent with one portion of the pedigree (Table 4). Rather than assume that the

Table 2. Characteristics of 14 microsatellite markers based on 44 walnut genotypes.

\begin{tabular}{|c|c|c|c|c|c|c|}
\hline & $\begin{array}{c}\text { GenBank } \\
\text { accession no. }^{z}\end{array}$ & $\mathrm{~N}^{\mathrm{y}}$ & Primer sequence ${ }^{x}$ & $\mathrm{H}_{\mathrm{O}}{ }^{\mathrm{w}}$ & $\mathrm{P}(\mathrm{ID})^{\mathrm{v}}$ & $\begin{array}{l}\text { Null allele } \\
\text { frequency estimate }\end{array}$ \\
\hline WGA001 & AY465952 & 6 & $\begin{array}{l}\text { ATTGGAAGGGAAGGGAAATG } \\
\text { CGCGCACATACGTAAATCAC }\end{array}$ & 0.57 & 0.17 & 0.06 \\
\hline WGA004 & AY465953 & 4 & $\begin{array}{l}\text { TGTTGCATTGACCCACTTGT } \\
\text { TAAGCCAACATGGTATGCCA }\end{array}$ & 0.41 & 0.29 & 0.13 \\
\hline WGA009 & AY465954 & 6 & $\begin{array}{l}\text { CATCAAAGCAAGCAATGGG } \\
\text { CCATTGCTCTGTGATTGGG }\end{array}$ & 0.59 & 0.21 & -0.03 \\
\hline WGA069 & AY465955 & 7 & $\begin{array}{l}\text { TTAGTTAGCAAACCCACCCG } \\
\text { AGATGCACAGACCAACCCTC }\end{array}$ & 0.57 & 0.11 & 0.12 \\
\hline WGA089 & AY465957 & 4 & $\begin{array}{l}\text { ACCCATCTTTCACGTGTGTG } \\
\text { TGCCTAATTAGCAATTTCCA }\end{array}$ & 0.61 & 0.21 & -0.02 \\
\hline WGA118 & AY465958 & 5 & $\begin{array}{l}\text { TGTGCTCTGATCTGCCTCC } \\
\text { GGGTGGGTGAAAAGTAGCAA }\end{array}$ & 0.55 & 0.21 & 0.03 \\
\hline WGA202 & AY465959 & 6 & $\begin{array}{l}\text { CCCATCTACCGTTGCACTTT } \\
\text { GCTGGTGGTTCTATCATGGG }\end{array}$ & 0.82 & 0.14 & -0.11 \\
\hline WGA225 & AY465960 & 3 & $\begin{array}{l}\text { AАTCCСТCTCCTGGGCAG } \\
\text { TGTTCCACTGACCACTTCCA }\end{array}$ & 0.64 & 0.22 & -0.04 \\
\hline WGA276 & AY465961 & 8 & $\begin{array}{l}\text { CTCACTTTCTCGGCTCTTCC } \\
\text { GGTCTTATGTGGGCAGTCGT }\end{array}$ & 0.52 & 0.12 & 0.10 \\
\hline WGA321 & AY465962 & 5 & $\begin{array}{l}\text { TCCAATCGAAACTCCAAAGG } \\
\text { GTCCAAAGACGATGATGGA }\end{array}$ & 0.59 & 0.09 & 0.12 \\
\hline WGA331 & AY465963 & 3 & $\begin{array}{l}\text { TCCCCCTGAAATCTTCTCCT } \\
\text { CGGTGGTGTAAGGCAAATG }\end{array}$ & 0.63 & 0.23 & -0.03 \\
\hline WGA332 & AY465964 & 4 & $\begin{array}{l}\text { ACGTCGTTCTGCACTCCTCT } \\
\text { GCCACAGGAACGAGTGCT }\end{array}$ & 0.52 & 0.20 & 0.09 \\
\hline WGA349 & AY465965 & 6 & $\begin{array}{l}\text { GTGGCGAAAGTTTATTTTTTGC } \\
\text { ACAAATGCACAGCAGCAAAC }\end{array}$ & 0.54 & 0.12 & 0.14 \\
\hline WGA376 & AY465966 & 6 & $\begin{array}{l}\text { GCCCTCAAAGTGATGAACGT } \\
\text { TCATCCATATTTACCCСTTTCG }\end{array}$ & 0.68 & 0.21 & -0.08 \\
\hline
\end{tabular}

zGenBank is the National Institute of Health's genetic sequence database.

yNumber of alleles observed for each marker.

xFoward primers are presented first.

wObserved heterozygosity for each marker.

vThe unbiased total probability of identity (Paetkau et al., 1995, 1998).

uNegative numbers denote an excess of observed hetetozygotes. 


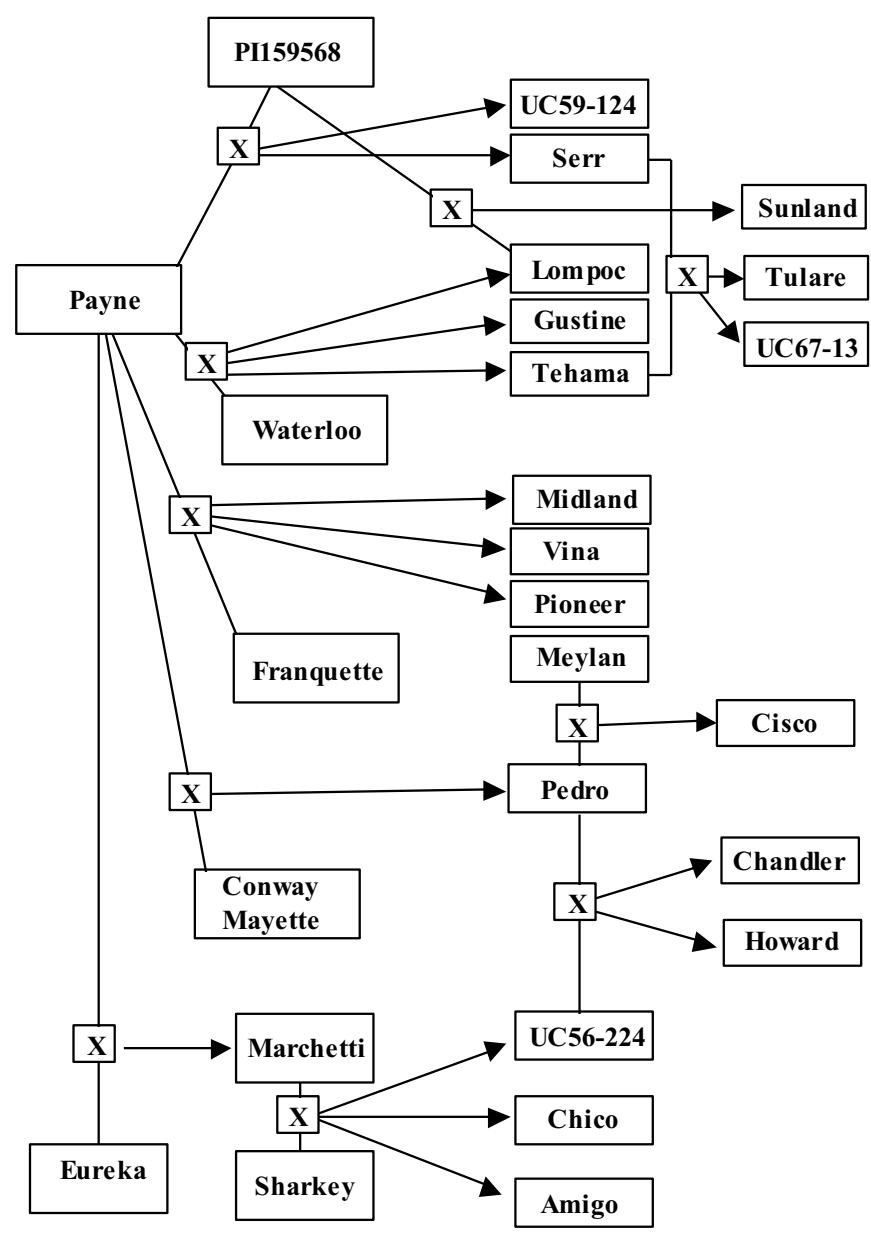

Fig. 1 (left). Pedigree showing relationships among 27 of the Juglans regia cultivars used in this study. Redrawn from Tulecke and McGranahan (1994).

published pedigree is incorrect, postulating a null allele in UC6713, inherited from 'Serr', explains the apparent discrepancy. Note that at WGA349, the accessions UC67-13, 'Serr', and PI159568, the parent from which 'Serr' would have had to inherit the null, were all initially scored as homozygotes (Table 4). The presumed null allele found in WGA331, on the other hand, is rare in the study set. The null allele can be viewed as one of seven alleles unique to Paradox 'Burbank' (Tables 3, 5). Given that Paradox hybrids are male sterile, the presence of a homozygous null in Paradox 'Burbank' may indicate that this genotype is actually the product of a backcross [i.e., (J. hindsii $\times$ J. regia) $\mathrm{x} J$. hindsii], a cross Luther Burbank is believed to have made (Howard, 1945; Whitson et al., 1914). The possibility that Paradox 'Burbank' is a backcross was further supported by the observation that it was homozygous at 10 of the 14 loci (Table 3 ). Interspecific hybrids might be expected to appear highly heterozygous unless $J$. hindsii contains a large number of null alleles.

Dendrograms are an efficient means of summarizing microsatellite data and can reveal relationships, including individuals with identical genotypes (Dangl et al., 2001). This data set contains three sets of cultivars with identical multi-locus profiles: 'Payne' and 'Ashley'; 'Lara' and UC61-25, and the three accessions of 'Franquette' (Fig. 2). 'Ashley' is said to be either a seedling or a sport of 'Payne' (Tulecke and McGranahan, 1994) since the two cultivars are nearly identical in phenotype and phenology (Hendricks et al., 1998). These data show that 'Ashley' is not a seedling of 'Payne'. Although a budsport origin is possible, the absence of clear phenotypic distinction between them suggests they are identical. Our data also do not distinguish 'Lara', a lat-

Table 3. Allele sizes (in base pairs) at 14 microsatellite loci for selected cultivars of Juglans regia and one hybrid.

\begin{tabular}{|c|c|c|c|c|c|c|c|c|c|c|c|c|c|c|}
\hline$\overline{\text { Cultivar }}$ & \multicolumn{2}{|c|}{ WGA001 } & \multicolumn{2}{|c|}{ WGA004 } & \multicolumn{2}{|c|}{ WGA009 } & \multicolumn{2}{|c|}{ WGA069 } & \multicolumn{2}{|c|}{ WGA089 } & \multicolumn{2}{|c|}{ WGA118 } & \multicolumn{2}{|c|}{ WGA202 } \\
\hline Chandler & 192 & 192 & 230 & 230 & 231 & 242 & 160 & 160 & 216 & 216 & 184 & 198 & 259 & 265 \\
\hline Cisco & 190 & 192 & 230 & 230 & 238 & 242 & 160 & 180 & 216 & 216 & 198 & 198 & 263 & 265 \\
\hline Franquette & 190 & 190 & 230 & 230 & 238 & 242 & 160 & 176 & 216 & 220 & 198 & 198 & 263 & 265 \\
\hline Howard & 192 & 192 & 228 & 230 & 242 & 242 & 160 & 160 & 216 & 220 & 196 & 198 & 259 & 263 \\
\hline Lozeronne & 190 & 190 & 230 & 230 & 242 & 242 & 160 & 180 & 212 & 220 & 196 & 198 & 263 & 265 \\
\hline Marchetti & 192 & 192 & 228 & 228 & 242 & 242 & 180 & 180 & 212 & 216 & 196 & 198 & 259 & 265 \\
\hline Paradox Burbank & 192 & 192 & 228 & 228 & 242 & $252^{z}$ & $164^{z}$ & $164^{z}$ & 216 & 216 & 189 & $209^{z}$ & $238^{z}$ & 265 \\
\hline Payne & 192 & 192 & 228 & 230 & 242 & 242 & 180 & 180 & 216 & 216 & 198 & 198 & 265 & 265 \\
\hline Placentia & 190 & 192 & 228 & 228 & 238 & 242 & 160 & 180 & 216 & 216 & 198 & 198 & 265 & 275 \\
\hline Serr & 180 & 192 & 230 & 238 & 238 & 242 & 178 & 180 & 216 & 218 & 184 & 198 & 259 & 265 \\
\hline Sharkey & 188 & 190 & 230 & 230 & 231 & 242 & 158 & 160 & 216 & 220 & 184 & 198 & 259 & 275 \\
\hline Sunland & 182 & 190 & 230 & 238 & 238 & 242 & 158 & 180 & 212 & 218 & 184 & 196 & 259 & 265 \\
\hline Cultivar & \multicolumn{2}{|c|}{ WGA225 } & \multicolumn{2}{|c|}{ WGA276 } & \multicolumn{2}{|c|}{ WGA321 } & \multicolumn{2}{|c|}{ WGA331 } & \multicolumn{2}{|c|}{ WGA332 } & \multicolumn{2}{|c|}{ WGA349 } & \multicolumn{2}{|c|}{ WGA376 } \\
\hline Chandler & 196 & 202 & 190 & 192 & 241 & 245 & 273 & 275 & 220 & 225 & 274 & 274 & 246 & 254 \\
\hline Cisco & 190 & 196 & 190 & 190 & 241 & 245 & 273 & 273 & 220 & 220 & 274 & 266 & 246 & 254 \\
\hline Franquette & 190 & 202 & 190 & 190 & 241 & 241 & 273 & 277 & 220 & 220 & 270 & 270 & 246 & 254 \\
\hline Howard & 196 & 196 & 190 & 192 & 245 & 245 & 275 & 277 & 220 & 225 & 274 & 274 & 254 & 254 \\
\hline Lozeronne & 190 & 202 & 190 & 190 & 224 & 241 & 273 & 273 & 214 & 223 & 262 & 270 & 242 & 254 \\
\hline Marchetti & 190 & 196 & 178 & 190 & 237 & 245 & 277 & 277 & 220 & 223 & 270 & 274 & 246 & 246 \\
\hline Paradox Burbank & 190 & 190 & 174 & 174 & 241 & 241 & null ${ }^{z}$ & nullz & 223 & 223 & $258^{z}$ & 270 & $218^{z}$ & $218^{z}$ \\
\hline Payne & 196 & 196 & 190 & 190 & 237 & 245 & 277 & 277 & 220 & 220 & 270 & 274 & 246 & 254 \\
\hline Placentia & 190 & 196 & 174 & 190 & 241 & 241 & 273 & 277 & 220 & 223 & 270 & 274 & 246 & 254 \\
\hline Serr & 196 & 196 & 172 & 190 & 222 & 237 & 273 & 277 & 214 & 220 & 274 & 274 & 246 & 254 \\
\hline Sharkey & 196 & 196 & 190 & 192 & 224 & 241 & 275 & 277 & 223 & 225 & 266 & 274 & 254 & 254 \\
\hline Sunland & 196 & 202 & 165 & 190 & 222 & 237 & 275 & 277 & 214 & 223 & 266 & 274 & 246 & 254 \\
\hline
\end{tabular}

'Alleles unique to Paradox 'Burbank'. 
Table 4. Inheritance of microsatellite alleles, including a null allele, at 14 loci through two generations of Juglans regia.

\begin{tabular}{|c|c|c|c|c|c|c|c|c|c|c|c|c|c|c|c|}
\hline \multirow{2}{*}{$\begin{array}{l}\text { Locus } \\
\text { WGA001 }\end{array}$} & \multicolumn{2}{|c|}{ PI-159568 } & \multirow[t]{2}{*}{$x$} & \multicolumn{2}{|c|}{ Payne } & $=$ & Serr & \multicolumn{2}{|c|}{ Tehama } & \multirow[t]{2}{*}{$=$} & \multicolumn{2}{|c|}{ UC67-13 } & \multirow[t]{2}{*}{ and } & \multicolumn{2}{|c|}{ Tulare } \\
\hline & ${\underline{180^{z}}}^{2}$ & 182 & & 192 & 192 & 180 & 192 & 190 & 192 & & 190 & 192 & & 180 & 190 \\
\hline WGA004 & $\overline{238}$ & $\underline{238}$ & & $\overline{228}$ & $\underline{230}$ & 230 & 238 & 228 & 228 & & 228 & 238 & & 228 & 238 \\
\hline WGA009 & 231 & $\overline{238}$ & & 242 & $\overline{242}$ & 238 & 242 & 242 & 242 & & 242 & 242 & & 238 & 242 \\
\hline WGA069 & 158 & $\underline{178}$ & & $\underline{180}$ & 180 & 178 & 180 & 180 & 180 & & 178 & 180 & & 178 & 180 \\
\hline WGA089 & $\underline{218}$ & $\overline{220}$ & & 216 & 216 & 216 & 218 & 216 & 220 & & 216 & 218 & & 216 & 216 \\
\hline WGA118 & $\underline{184}$ & 186 & & $\underline{198}$ & 198 & 184 & 198 & 196 & 198 & & 184 & 198 & & 196 & 198 \\
\hline WGA202 & $\overline{245}$ & $\underline{259}$ & & $\overline{265}$ & 265 & 259 & 265 & 265 & 265 & & 259 & 265 & & 259 & 265 \\
\hline WGA225 & $\underline{196}$ & 202 & & $\underline{196}$ & 196 & 196 & 196 & 190 & 196 & & 190 & 196 & & 196 & 196 \\
\hline WGA276 & 165 & 172 & & 190 & 190 & 172 & 190 & 178 & 190 & & 172 & 190 & & 172 & 190 \\
\hline WGA321 & $\underline{222}$ & 237 & & $\underline{237}$ & 245 & 222 & 237 & 237 & 237 & & 222 & 237 & & 222 & 237 \\
\hline WGA331 & $\underline{273}$ & 275 & & $\underline{277}$ & 277 & 273 & 277 & 273 & 277 & & 273 & 273 & & 273 & 277 \\
\hline WGA332 & $\underline{214}$ & 214 & & $\underline{220}$ & 220 & 214 & 220 & 220 & 220 & & 220 & 220 & & 214 & 220 \\
\hline WGA349 & 266 & $\underline{\text { nully }}$ & & 270 & $\underline{274}$ & 274 & null & 262 & 270 & & 270 & null & & 262 & 274 \\
\hline WGA376 & $\underline{254}$ & 254 & & $\underline{246}$ & 254 & 246 & 254 & 254 & 254 & & 254 & 254 & & 254 & 254 \\
\hline
\end{tabular}

"Alleles inherited by 'Serr' have been underlined.

y A single fragment was observed in all cases where null alleles are presumed.

Table 5. Frequencies of observed alleles at 14 microsatellite loci based on 44 Juglans genotypes.

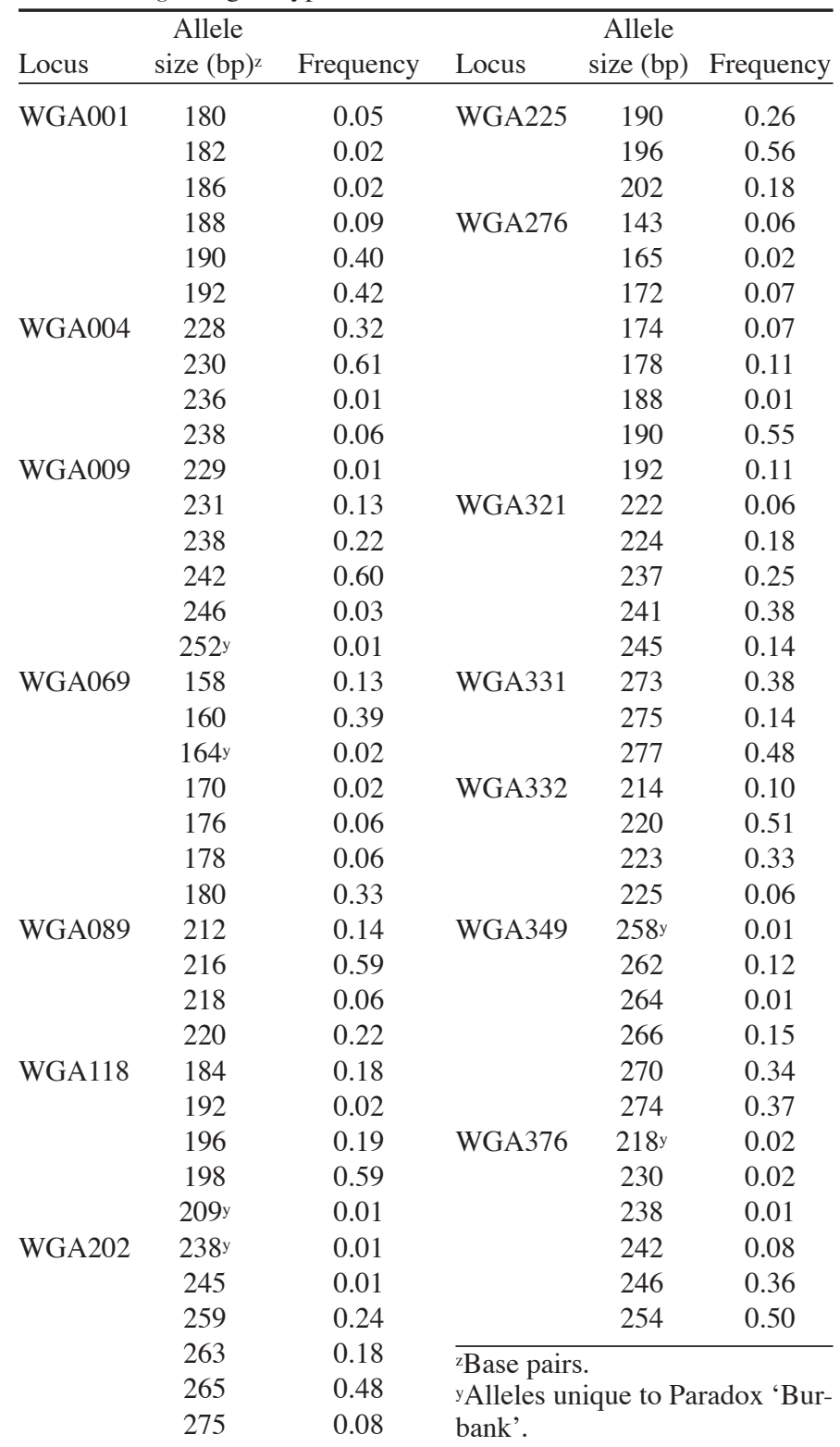

eral-bearing, early-blooming French cultivar, from UC61-25, a Univ. of California selection that was never released as a named cultivar. The phenotypic similarity of these two cultivars has been noted (Tulecke and McGranahan, 1994); they are believed to be synonyms. A century ago, many walnut growers thought cultivars could be propagated true-to-type by seed as well as by grafting. 'Franquette', a French cultivar, and at that time a leading cultivar in northern California, was commonly propagated by both methods. In the 1950s, the Univ. of California Walnut Breeding Program collected 'Franquette' types from several orchards to compare their performance. The various Franquettes were said to be the original introduced cultivar, budsports, or seedlings with phenotypes similar to the parent. None were found superior to the original (Tulecke and McGranahan, 1994). Two of the best, 'Scharsh Franquette' and 'Graves Franquette', were retained in the collection. The data indicate that these are not 'Franquette' seedlings and they were not distinguished from the original cultivar (Fig. 2). 'Early Ehrhardt' and 'Placentia' differ at only one locus. This close relationship, reflected in Figure 2, is not surprising as both originated from a narrow germplasm base in southern California (Tulecke and McGranahan, 1994).

Other features of Figure 2 are consistent with what is known regarding the study group. Paradox 'Burbank', 'Sinensis-5', 'Weeper', and 'Alsoszentivani-117', on the top of Figure 2, are shown to be different from each other and from the rest of the study set. Paradox 'Burbank' is the only interspecific hybrid in the study set. 'Sinensis-5', sent from Japan as a distinct species, $J$. sinensis, appears to be within the variation seen in J. regia. 'Weeper' exhibits a weeping growth habit and is the only such example in the collection. 'Alsoszentivani-117' is the only selection in the set from central Europe. The outlying positions of 'Xinjiang' and 'Manregian' are consistent with their origins in separate regions of China. They are phenotypically distinct, and the only two Chinese introductions in the study.

We had no prior information regarding the level of polymorphism of these loci in J. nigra. The average of 5.2 alleles per locus (Table 2 ) is lower than other clonally propagated crops ( Bowers et al., 1999; Hokanson et al., 1998). Others have observed a decrease in polymorphism when loci cloned from one species are used in related species (Aldrich et al., 2003; Peakall et al., 1998). But the low number of alleles in this study is best attributed to the narrow germplasm in the study group. The many high frequency 




Fig. 2. Dendrogram generated using unweighted pair group method with arithmetic mean cluster analysis based on the proportion of shared alleles (Bowcock et al., 1994) among 48 Juglans genotypes.

alleles (Table 5) are most likely due to the prominence of 'Payne' in the pedigree (Fig. 1). The unbiased P(ID) for all loci and all genotypes was about $10^{-11}$, indicating the power of these loci to uniquely identify genotypes, even among the narrow and biased germplasm selected for this study. The random match probability for the profile of 'Lozeronne', a French cultivar unrelated to any other genotype in the study set, is $3.5 \times 10^{-13}$. To put these numbers in perspective, the probability of a match between two unrelated people is approximately $10^{-13}$ (Gill, 2002).

In summary, the described markers were able to distinguish specific pairs of closely related cultivars and to uniquely identify all walnut cultivars with the exception of budsports. They will be useful for the characterization and comparison of germplasm collections and the detection of propagation errors. The markers 
generated data consistent with published pedigrees and thus could assist in documenting breeding programs. They also consistently amplified in a $J$. hindsii $\times$ J. regia hybrid, demonstrating their utility in future studies of rootstock production.

\section{Literature Cited}

Aldrich, P., M. Jagtap, C.H. Michler, and J. Romero-Severson. 2003. Amplification of North American red oak microsatellite markers in european white oak and chinese chestnut. Silvae Genet. 52:176-179.

Arulsekar, S., D.E. Parfitt, and G.H. McGranahan. 1985. Isozyme gene markers in Juglans species. J. Hered. 76:103-106.

Bowcock, A.M., A. Ruiz-Linares, J. Tomfohrde, E. Minch, J.R. Kidd, and L.L. Cavalli-Sforza. 1994. High resolution of human evolutionary trees with polymorphic microsatellites. Nature 368:455-457.

Bowers, J.E., G.S. Dangl, and C.P. Meredith. 1999. Development and characterization of additional microsatellite DNA markers for grape. Amer. J. Enol. Viticult. 50:243-246.

Dangl, G.S., M.L. Mendum, B.H. Prins, M.A. Walker, C.P. Meredith, and C.J. Simon. 2001. Simple sequence repeat analysis of a clonally propagated species: A tool for managing a grape germplasm collection. Genome 44:432-438.

Doyle, J. and J. Doyle. 1987. A rapid DNA isolation procedure for small quantities of fresh leaf tissue. Phytochem. Bul. 19:11-15.

Fjellstrom, R.G., D.E. Parfitt, and G.H. McGranahan. 1994. Genetic relationships and characterization of persian walnut (Juglans regia L.) cultivars using restriction fragment length polymorphisms (RFLPs). J. Amer. Soc. Hort. Sci. 119:833-839.

Gill, P. 2002. Role of short tandem repeat DNA in forensic casework in the UK-Past, present, and future perspectives. BioTechniques 32:366-385.

Hendricks, L.H., W.M. Coates, R.B. Elkins, G.H. McGranahan, H. Phillips, D. Ramos, W.O. Reil, and R.G. Snyder. 1998. Selection of varieties, p. 84-89. In: D. Ramos (ed.). Walnut production manual. Publ. 3373. Univ. of California Div. Agr. and Natural Resources, Oakland.

Hokanson, S.C., A.K. Szewc-McFadden, W.F. Lamboy, and J.R. McFerson. 1998. Microsatellite(SSR) markers reveal genetic identities, genetic diversity and relationships in a Malus $\times$ domestica Borkh. core subset collection. Theor. Appl. Genet. 97:671-683.

Howard, W.L. 1945. Luther Burbank's plant contributions. California Agr. Expt. Sta. Bul. 691.

McGranahan, G.H., D.G. Voyiatzis, P.B. Catlin, and V.S. Polito. 1994. High pollen loads can cause pistillate flower abscission in walnut. J. Amer. Soc. Hort. Sci. 119:505-509.

Marshall, T.C., J. Slate, L.E.B. Kruuk, and J.M. Pemberton. 1998. Statistical confidence for likelihood-based paternity inference in natural populations. Mol. Ecol. 7:639-655.

Minch, E., A. Ruiz-Linares, D. Goldstein, M. Feldman, J.R. Kidd, and L.L. Cavalli-Sforza. 1997. Microsat 1.5: A computer program for calculating various statistics on microsatellite allele data. 21 Aug. 2004. $<\mathrm{http}: / /$ hpgl.stanford.edu/projects/microsat/>.

Mircetich, S.M.J., A. Rowhani, and D. Ramos. 1985. Blackline disease, p. 142-152. In: D. Ramos (ed.). Walnut orchard management. Publ. 21410. Regents Univ. of California. Div. Agr. Natural Resources, Oakland.

Mitchell, S.E., S. Kresovich, C.A. Jester, C.J. Hernandez, and A.K.
Szewc-McFadden. 1997. Application of multiplex PCR and fluorescence-based, semi-automated sizing technology for genotyping plant genetic resources. Crop Sci. 37:617-624.

Nicese, F.P., J.I. Hormaza, and G.H. McGranahan. 1998. Molecular characterization and genetic relatedness among walnut (Juglans regia L.) genotypes based on RAPD markers. Euphytica 101:199-206.

Paetkau, D., W. Calvert, I. Stirling, and C. Strobeck. 1995. Microsatellite analysis of population structure in Canadian polar bears. Mol. Ecol. 4:347-354.

Paetkau, D., L.P. Waits, P.L. Clarkson, L. Craighead, E. Vyse, R. Ward, and C. Strobeck. 1998. Variation in genetic diversity across the range of North American brown bears. Conservation Biol. 12:418-429.

Peakall, R., S. Gilmore, W. Keys, M. Morgante, and A. Rafalski. 1998. Cross-species amplification of soybean (Glycine max) simple sequence repeats (SSRs) within the genus and other legume genera: Implications for the transferability of SSRs in plants. Mol. Biol. Evol. 15:1275-1287.

Phippen, W.B., S. Kresovich, F. Gonzalez-Candelas, and J.R. McFerson. 1997. Molecular characterization can discriminate and partition variation among genebank holdings: A case study with phenotypically similar accessions of Brassica oleracea L. var. capitata (cabbage) 'Golden Acre'. Theor. Appl. Genet. 94:227-234.

Potter, D., F. Gao, G. Aiello, C. Leslie, and G. McGranahan. 2002a. Intersimple sequence repeat markers for fingerprinting and determining genetic relationships of walnut (Juglans regia) cultivars. J. Amer. Soc. Hort. Sci. 127:75-81

Potter, D., F. Gao, S. Baggett, J.A. McKenna, and G.H. McGranahan. 2002b. Defining the source of Paradox: DNA sequence markers for North American walnut (Juglans L.) species and hybrids. Scientia Hort. 94:157-170.

Sneath, P.H.A. and R.R. Sokal. 1973. Numerical taxonomy: The principles and practice of numerical classification. Freeman, San Francisco.

Solar, A., J. Smole, and F. Stampar. 1993. Identification of walnut cultivars by pollen isozymes. Acta Hort. 311:95-99.

Solar, A., J. Smole, and F. Stampar. 1994. Characterization of isozyme variation in walnut (Juglans regia L.). Euphytica 77:105-112.

This, P., A. Jung, P. Boccacci, J. Borrego, R. Botta, L. Costantini, M. Crespan, G.S. Dangl, C. Eisenheld, F. Ferreira-Monteiro, S. Grando, J. Ibáñez, T. Lacombe, V. Laucou, M. Magalhães, C.P. Meredith, N. Milani, E. Peterlunger, F. Regner, L. Zulini, and E. Dettweiler. 2004. Development of a standard set of microsatellite reference alleles for identification of grape cultivars. Theor. Appl. Genet. 109:1448-1458.

Tulecke, W. and G. McGranahan. 1994. The walnut germplasm collection of the University of California, Davis: A description of the collection and a history of the breeding program of Eugene F. Serr and Harold I. Forde. Rpt. 13. Univ. Calif. Genet. Resources Conservation Program, Davis.

Whitson, J., R. John, and H.S. Williams (eds.). 1914. Luther Burbank, his methods and discoveries and their practical application. Vol. 2. Luther Burbank Press, New York.

Woeste, K., R. Burns, O. Rhodes, and C. Michler. 2002. Thirty polymorphic nuclear microsatellite loci from black walnut. J. Hered. 93:58-60. 